\title{
DNA-DNA Hybridization Studies and Phenotypic Characteristics of Strains within the 'Streptococcus milleri Group'
}

\author{
By ROBERT A. WHILEY* AND JEREMY M. HARDIE \\ Department of Oral Microbiology, The London Hospital Medical College, London E1 2AD, UK
}

(Received 4 April 1989; revised 26 June 1989; accepted 4 July 1989)

\begin{abstract}
Twenty-five strains resembling 'Streptococcus milleri' were compared by DNA-DNA hybridization, by whole-cell-derived polypeptide patterns on SDS-PAGE, and by biochemical tests. Four homology groups were revealed by DNA-DNA hybridization. DNA homology groups 1, 2 and 3 were closely related and contained the type strains NCDO 2226 (Streptococcus constellatus), NCDO 2227 (Streptococcus intermedius) and NCTC 10713 (Streptococcus anginosus), respectively. DNA homology group 4 consisted of four strains received as variants of Streptococcus intermedius which were found not to be closely related to strains in groups $1-3$. The data from SDS-PAGE polypeptide patterns and biochemical tests supported the recognition of three centres of variation within the 'Streptococcus milleri group' corresponding to DNA homology groups 1-3 and indicated that strains of DNA homology group 4 are members of an as yet undescribed species within the viridans streptococci.
\end{abstract}

\section{INTRODUCTION}

'Streptococcus milleri' is the name frequently used for a group of streptococci that form part of the normal flora of the human mouth and upper respiratory, intestinal and urinogenital tracts (Attebury et al., 1972; Mejare \& Edwardsson, 1975; Poole \& Wilson, 1979; Ruoff \& Kunz, 1982). In recent years these bacteria have increasingly been recognized as having clinical importance, particularly by their association with abscesses and other purulent infections (Parker \& Ball, 1976; Ball \& Parker, 1979; Poole \& Wilson, 1979; Shlaes et al., 1981 ; Gossling, 1988). Despite the accumulated evidence for the pathogenicity of these bacteria (see Gossling, 1988 , for a review of the literature) there is still disagreement about the taxonomy and nomenclature of the ' $S$. milleri group' (Hardie, 1986).

The name 'Streptococcus milleri' was first proposed by Guthof (1956) for a group of nonhaemolytic streptococci isolated from abscesses of the oral cavity that grew on $40 \%$ bile agar and at $45{ }^{\circ} \mathrm{C}$, hydrolysed aesculin and arginine but did not produce acid from mannitol or sorbitol. On the basis of cell wall analysis, numerical taxonomy and DNA transformation studies, Colman \& Williams (1972) broadened the description to include those previously reported nonhaemolytic streptococci isolated from the human respiratory tract and called 'Streptococcus $M G$ ' (Mirick et al., 1944), the haemolytic and non-haemolytic streptococci possessing the so-called type antigens of Lancefield group F (Ottens \& Winkler, 1962) and the minute-colony-forming streptococci of Lancefield groups F and G (Long \& Bliss, 1934; Bliss, 1937). Subsequently, Facklam (1977) reported a high degree of similarity between 'Streptococcus MG' (Mirick et al., 1944), Streptococcus intermedius (Holdeman \& Moore, 1974), Streptococcus anginosus (Andrewes \& Horder, 1906; Deibel \& Seeley, 1974) and Streptococcus constellatus (Holdeman \& Moore, 1974). Facklam (1977) chose to divide these non-haemolytic, 'milleri-like' streptococci into two groups on the basis of lactose fermentation, namely 'Streptococcus MG-intermedius' (lactose fermenters) and 'Streptococcus anginosus-constellatus' (lactose non-fermenters). In an attempt to clarify the situation in which different names were used in Europe and the United States, it was suggested that $\beta$-haemolytic strains (whether or not they possessed Lancefield group antigens), 
be called Streptococcus anginosus, while non- $\beta$-haemolytic strains be divided into Streptococcus intermedius (lactose fermenters) and Streptococcus constellatus (lactose non-fermenters) (Facklam, 1984, 1985). Despite the differences in nomenclature, several taxonomic studies have demonstrated a high degree of phenotypic similarity and a close relationship between strains resembling 'S. milleri' (Mejare, 1975; Lutticken et al., 1978; Labbe et al., 1985; Coykendall et al., 1987; French et al., 1989). However, heterogeneity within the 'Streptococcus milleri group' has been reported on the basis of several different criteria that include fermentation patterns (Poole \& Wilson, 1979; Ruoff \& Kunz, 1982; Drucker \& Lee, 1981), long-chain fatty acid analysis (Drucker \& Lee, 1981; Cookson et al., 1989), DNA base composition determinations (mol\% G + C) (Drucker \& Lee, 1983), antigenic composition (Colman \& Williams, 1972; Lutticken et al., 1978; Yakushiji et al., 1988) and multilocus enzyme electrophoresis (Gilmour et al., 1987).

Evidence from DNA-DNA hybridization studies has been somewhat contradictory. Some authors have concluded that strains resembling ' $S$. milleri' should be included within a single homology group (Welborn et al., 1983; Farrow \& Collins, 1984; Ezaki et al., 1986; Coykendall et al., 1987) whereas others have demonstrated the presence of more than one DNA homology group (Kilpper-Balz et al., 1984; Knight \& Shlaes, 1988). Coykendall et al. (1987) proposed that strains variously described as ' $S$. milleri', $S$. constellatus and $S$. intermedius be included within a single species, $S$. anginosus. Subsequently, however, strains identified as $S$. intermedius were observed to fall into three DNA homology groups (Knight \& Shlaes, 1988). In addition, a preliminary DNA-DNA hybridization experiment in our own laboratory indicated that the type strains of $S$. anginosus, $S$. constellatus and $S$. intermedius belonged to separate homology groups (Whiley, 1987).

In view of the continued confusion surrounding the taxonomy of strains resembling ' $S$. milleri', we decided to carry out extensive DNA-DNA hybridization experiments together with phenotypic characterization on a representative collection of clinical and reference strains, in an effort to clarify the taxonomic structure of the 'Streptococcus milleri group'.

\section{METHODS}

Bacterial strains and growth conditions. The strains and their sources are given in Table 1. Unless otherwise stated, incubation was at $37^{\circ} \mathrm{C}$ in an anaerobic atmosphere of $\mathrm{H}_{2} / \mathrm{CO}_{2} / \mathrm{N}_{2}$ (20:10:70, by vol.). For DNA preparation, strains were cultivated in 2 or 3 litres of Streptococcus Sugar Base broth (SSB), containing 2\% (w/v) protease peptone (Oxoid), $0.5 \%$ (w/v) yeast extract (Difco), $0.5 \%$ (w/v) $\mathrm{NaCl}, 0.1 \%(\mathrm{w} / \mathrm{v}) \mathrm{Na}_{2} \mathrm{HPO}_{4}, \mathrm{pH} 7.6$, supplemented with $0.5 \%(\mathrm{w} / \mathrm{v})$ glucose and $0.25 \%(\mathrm{w} / \mathrm{v}) \mathrm{NaHCO}_{3}$. Cells were harvested in the late exponential phase by centrifugation.

Preparation of DNA. DNA was isolated and purified from approximately $3 \mathrm{~g}$ (wet weight) of cells by the method of Garvie (1976). Radioactive DNA was labelled with deoxy $\left[1^{\prime}, 2^{\prime}, 5-{ }^{3} \mathrm{H}\right]$ cytidine triphosphate (Amersham) by nick-translation using a commercial kit (Amersham).

DNA base composition determinations. The thermal denaturation method of Marmur \& Doty (1962) was used to determine the guanine $(\mathrm{G})$ plus cytosine $(\mathrm{C})$ content $(\mathrm{mol} \% \mathrm{G}+\mathrm{C})$ of the DNA. Determinations were performed in duplicate in standard saline citrate (SSC: $0.15 \mathrm{M}-\mathrm{NaCl}$ plus $0.015 \mathrm{M}$-trisodium citrate, $\mathrm{pH} 7.0$ ) as described previously (Beighton et al., 1984). The mol \% G + C was calculated after Owen \& Hill (1979) using the following equation: $\mathrm{mol} \% \mathrm{G}+\mathrm{C}=50.9+2.44\left(T_{\mathrm{mX}}-T_{\mathrm{m} R}\right.$ where $T_{\mathrm{mX}}$ is the melting temperature of DNA from the test strain and $T_{\mathrm{m} R}$ is the melting temperature of DNA from Escherichia coli strain NCTC 9001.

DNA-DNA hybridizations. These were done using the S1-nuclease method of Crosa et al. (1973) as modified by Shah et al. (1982). Hybridizations were performed, in triplicate, in $300 \mu \mathrm{l} 0.42 \mathrm{M}-\mathrm{NaCl}$ containing sheared, denatured, unlabelled DNA $(30 \mu \mathrm{g})$ and sheared, denatured, labelled DNA (0.02 $\mu \mathrm{g})$. Experiments were done under optimum $\left(60^{\circ} \mathrm{C}\right)$ and stringent $\left(75^{\circ} \mathrm{C}\right)$ conditions for $90 \mathrm{~h}$ to obtain a $C_{0} t$ value of 100 (Britten \& Kohne, 1968). After incubation, hybridization mixtures were cooled in an ice bath and treated with $540 \mu 1$ ice-cold S1nuclease buffer $\left(0.4 \mathrm{mM}-\mathrm{ZnSO}_{4}, 0.15 \mathrm{M}-\mathrm{NaCl}, 0.03 \mathrm{M}\right.$-sodium acetate, $\left.\mathrm{pH} 4.8\right)$ containing $30 \mu \mathrm{g}$ sheared denatured calf thymus DNA ml-1 and 20 units S1-nuclease (Boehringer). The mixtures were incubated at $50^{\circ} \mathrm{C}$ for $30 \mathrm{~min}$ before the addition of $250 \mu \mathrm{l}$ ice-cold $25 \%(\mathrm{w} / \mathrm{v})$ trichloracetic acid. The S1-nuclease-treated duplexes were trapped on glass-fibre filters (Whatman GF/F) and washed with 3 vols ice-cold $5 \%(w / v)$ trichloracetic acid. The filters were dried and their radioactivity measured by scintillation counting. Controls included a homologous reassociation as a positive $(100 \%)$ control and calf thymus DNA as a negative $(0 \%)$ control. For each test DNA the degree of sequence homology was expressed as a percentage of the homologous control after correction for selfreassociation in the negative control.

Biochemical tests. Acid production from carbohydrates, etc. (arabinose, amygdalin, cellobiose, glucose, glycerol, 
Table 1. Details of Streptococcus strains

Name/strain code

$S$. anginosus

NCTC $10713^{\mathrm{T}}$ (ATCC 12395', DSM 20563')

$S$. intermedius

NCDO $2227^{\mathrm{T}}\left(\right.$ ATCC $27335^{\mathrm{T}}$, DSM 20573 )

CDC : $415-87$

CDC: $1007-77$

CDC: $2236-81$

CDC: $2405-81$

$S$. intermedius variant strains

CDC: SS-895 (ATCC 15909)

CDC: SS-898 (ATCC 15912)

CDC : $2156-81$

CDC : $85-81$

$S$. constellatus

NCDO $2226^{\mathrm{T}}\left(\right.$ ATCC $27823^{\mathrm{T}}$, NCTC $11325^{\mathrm{T}}$, DSM 20575')

'S. milleri'

NMH 2

NMH 10

KR 455

KR 687

AM 699

PC 4890

UNS 35

G5:3

NCTC 11062

NCTC 11063

'Streptococcus $M G$ '

NCTC 8037

ATCC 9895 (' $S$. mitis-MG')

'Streptococcus sp. group F'

NCTC 5389

NCTC 10714

$S$. sanguis

NCTC $7863^{\mathrm{T}}$ (ATCC $10556^{\mathrm{T}}$, DSM $20567^{\mathrm{T}}$ )

S. mitis

NCTC $3165^{\mathrm{T}}$ (ATCC 33399 ${ }^{\mathrm{T}}$, DSM 20568 ${ }^{\mathrm{T}}$ )

S. oralis

LVG1 $^{\mathrm{T}}$ (NCTC $11427^{\mathrm{T}}$ )

S. salivarius

NCTC $8618^{\mathrm{T}}\left(\right.$ DSM $\left.20560^{\mathrm{T}}\right)$

$S$. vestibularis

$\mathrm{MM1}^{\mathrm{T}}$ (NCTC $12166^{\mathrm{T}}$, ATCC 49124')

S. mutans

NCTC $10449^{\mathrm{T}}\left(\right.$ ATCC $25175^{\mathrm{T}}$, DSM 20523 ${ }^{\mathrm{T}}$ )
Lancefield group (as received)

Source

(human)

Throat

Unknown

Brain abscess

Wound

Blood

Blood

Throat

Throat

Blood

Blood

Purulent pleurisy

Brain abscess

Perforated ulcer

Urine

Axillary abscess

Dental plaque

Dental plaque

Brain abscess

Dental plaque

Root canal

Throat

Respiratory tract

Throat

Unknown

Throat

Subacute bacterial endocarditis

Pyorrhoea

Mouth

Throat

Mouth

Carious dentine

* T, Type strain; ATCC, American Type Culture Collection, Rockville, Maryland, USA; NCTC, National Collection of Type Cultures, Central Public Health Laboratory, Colindale, London, UK; CDC, strains from Dr R. Facklam, Center for Disease Control, Atlanta, Georgia, USA; DSM, Deutsche Sammlung von Mikroorganismen, Gottingen, FRG; KR, strains from Dr K. Ruoff, Massachusetts General Hospital, Massachusetts, USA; NMH, strains from Mr M. W. D. Wren, North Middlesex Hospital, London N18, UK; PC, AM, strains from the Department of Oral Microbiology, The London Hospital Medical College, London, UK; G, strain from Dr B. Mejare, School of Dentistry, University of Lund, Malmo, Sweden; UNS, Dr P. Unsworth, Central Public Health Laboratory, Colindale, UK.

inulin, lactose, mannitol, melibiose, raffinose, salicin, sorbitol and trehalose) was tested for in microtitre trays by the method of Beighton et al. (1981). The ability to produce acetoin (VP test) was determined as described by Cowan (1974). Aesculin hydrolysis and the production of ammonia from arginine were tested according to Bisset \& Davis (1960); the production of ammonia from arginine was detected by the addition of Nessler's reagent. Starch hydrolysis was tested on brain heart infusion medium (Difco) supplemented with $0.2 \%(w / v)$ soluble starch and 
$1.2 \%(w / v)$ agar (Oxoid no. 1). After $5 \mathrm{~d}$ incubation, plates were flooded with Lugol's iodine; the hydrolysis of starch was indicated by the appearance of clear zones around the colonies. Hydrogen peroxide production was tested for by the method of Whittenbury (1964) as described previously (Whiley \& Hardie, 1988), with strains incubated in $10 \% \mathrm{CO}_{2}$-in-air at $37{ }^{\circ} \mathrm{C}$ for $4 \mathrm{~d}$. Hydrogen peroxide production was detected when the surrounding medium became dark brown or black.

API 20 STREP. All test strains were examined using the API 20 STREP rapid identification kit according to the manufacturer's instructions.

Haemolysis. Strains were streaked onto blood agar plates containing blood agar base $\left(40 \mathrm{~g} \mathrm{I}^{-1}\right.$; Oxoid) plus $5 \%$ (v/v) defibrinated horse blood (Gibco) and incubated for $48 \mathrm{~h}$ anaerobically before the type of haemolysis produced $(\alpha, \beta$ or $\gamma)$ was recorded.

Hyaluronidase production. This was tested for by the rapid plate method of Smith \& Willet (1968). To a basal medium consisting of brain heart infusion and $1 \%(\mathrm{w} / \mathrm{v})$ agar (Oxoid no. 1) were added filter-sterilized, aqueous solutions of hyaluronic acid $\left(4 \mathrm{mg} \mathrm{ml}^{-1}\right.$; Sigma, grade III-S) and $5 \%(\mathrm{v} / \mathrm{v})$ bovine serum albumin fraction $\mathrm{V}$ (Sigma) to final concentrations of $400 \mu \mathrm{g} \mathrm{ml}^{-1}$ and $1 \%(\mathrm{w} / \mathrm{v})$ respectively. Plates were poured (3-4 mm depth) and strains were inoculated onto the agar surface in discrete spots. Incubation was carried out for $48 \mathrm{~h}$ under anaerobic conditions. After incubation the plates were flooded with $2 \mathrm{M}$-acetic acid for $10 \mathrm{~min}$. Strains producing hyaluronidase were identified by the appearance of a clear zone around the growth.

Comparison of strains by SDS-PAGE. Whole-cell-derived polypeptide patterns were obtained by SDS-PAGE, done in both $7 \%$ and $12 \%(\mathrm{w} / \mathrm{v})$ polyacrylamide slab gels using the discontinuous buffer system of Laemmli (1970). Approximately $60 \mu \mathrm{g}$ of sample protein from each strain, prepared as described previously (Whiley et al., 1982), was loaded into each well. After electrophoresis was completed the polypeptide patterns were visualized by staining with Coomassie Brilliant Blue-R (Sigma).

\section{RESULTS}

\section{DNA studies}

The $\mathrm{mol} \% \mathrm{G}+\mathrm{C}$ contents of the test strains and the results of the DNA-DNA hybridization experiments are shown in Table 2 . The $\mathrm{mol} \% \mathrm{G}+\mathrm{C}$ range of $36 \cdot 7-39 \cdot 5$ for homology groups 1-3 is in good agreement with values obtained in previous studies on strains resembling ' $S$. milleri' (Kilpper-Balz et al., 1984; Ezaki et al., 1986; Coykendall et al., 1987). However, the $\mathrm{mol} \% \mathrm{G}+\mathrm{C}$ range within homology group $4(41 \cdot 5-42 \cdot 7)$ falls outside that of most published data on this group of bacteria, although values as high as $43 \%$ were obtained by Drucker \& Lee (1983).

The 25 strains resembling ' $S$. milleri' fell into four DNA homology groups (1-4), with members within a group exhibiting a high degree of base sequence homology under both optimum and stringent hybridization conditions. A higher degree of intergroup relatedness was observed between groups 1, 2 and 3 than was seen between any of these groups and homology group 4 . In most cases the latter group showed $<30 \%$ homology with the other groups under optimum conditions. Homology group $1(\mathrm{~mol} \% \mathrm{G}+\mathrm{C} 36 \cdot 7-38 \cdot 5)$ contained reference strains of $S$. constellatus (NCDO 2226), Lancefield group F (NCTC 5389 and NCTC 10714) and 'S. milleri' (NCTC 11063), together with 'S. milleri' strain AM 699, isolated from dental plaque. Homology group $2(\mathrm{~mol} \% \mathrm{G}+\mathrm{C} 37 \cdot 2-38 \cdot 5)$ included the reference strain of $S$. intermedius (NCDO 2227) together with three strains isolated from brain abscesses: ' $S$. milleri' NMH 2 and UNS 35, and $S$. intermedius 415-87. Homology group $3(\mathrm{~mol} \% \mathrm{G}+\mathrm{C} 38 \cdot 1-39 \cdot 5)$ contained the type strain of $S$. anginosus (NCTC 10713), reference strains of 'Streptococcus $M G$ ' (NCTC 8037, ATCC 9895) and ' $S$. milleri' (NCTC 11062) together with strains designated as ' $S$. milleri' and $S$. intermedius that had been isolated from dental plaque, wound swabs, blood, an axillary abscess and urine. Homology group $4(\mathrm{~mol} \% \mathrm{G}+\mathrm{C} 41 \cdot 5-42 \cdot 7)$ consisted of the four variant strains of $S$. intermedius obtained from Dr R. Facklam of the CDC, Atlanta, Georgia, USA, that had been isolated from blood cultures and human throats.

\section{Biochemical characteristics}

The biochemical test results for the strains are shown in Table 3. All 25 test strains produced acid from glucose but none was able to ferment arabinose, glycerol or inulin. Virtually all strains failed to ferment mannitol or sorbitol. Most strains produced acetoin, hydrolysed arginine and fermented salicin and trehalose but failed to ferment melibiose or raffinose. Strains comprising DNA homology group 1 were characterized by not fermenting lactose or amygdalin, in not producing hydrogen peroxide and in being mainly $\beta$-haemolytic. Most strains in homology 
Table 2. DNA homologies of strains resembling 'S. milleri' using optimum $\left(60^{\circ} \mathrm{C}\right)$ and stringent $\left(75^{\circ} \mathrm{C}\right)$ hybridization conditions

\begin{tabular}{|c|c|c|c|c|c|c|c|c|c|}
\hline \multirow{3}{*}{$\begin{array}{l}\text { Unlabelled DNA } \\
\text { from: }\end{array}$} & \multirow{3}{*}{$\begin{array}{l}\mathrm{Mol} \% \\
\mathrm{G}+\mathrm{C}\end{array}$} & \multicolumn{8}{|c|}{$\begin{array}{l}\text { Percentage DNA homology* } \\
\text { using }{ }^{3} \mathrm{H} \text {-labelled DNA from: }\end{array}$} \\
\hline & & \multicolumn{2}{|c|}{ NCDO $2226^{T}$} & \multicolumn{2}{|c|}{ NCDO $2227^{\mathrm{T}}$} & \multicolumn{2}{|c|}{ NCTC $10713^{T}$} & \multicolumn{2}{|c|}{$85-81$} \\
\hline & & $60^{\circ} \mathrm{C}$ & $75^{\circ} \mathrm{C}$ & $60^{\circ} \mathrm{C}$ & $75^{\circ} \mathrm{C}$ & $60^{\circ} \mathrm{C}$ & $75^{\circ} \mathrm{C}$ & $60^{\circ} \mathrm{C}$ & $75^{\circ} \mathrm{C}$ \\
\hline \multicolumn{10}{|l|}{ Homology group I } \\
\hline NCDO $2226^{\mathrm{T}}$ & $36 \cdot 7$ & 100 & 100 & 70 & 40 & 57 & 24 & 24 & NT \\
\hline AM 699 & $38 \cdot 5$ & 122 & 78 & NT & NT & 56 & 22 & 24 & NT \\
\hline NCTC 10714 & $38 \cdot 5$ & 72 & 102 & 69 & 35 & 44 & NT & NT & NT \\
\hline NCTC 11063 & $38 \cdot 5$ & 101 & 98 & 58 & 19 & 44 & NT & NT & NT \\
\hline NCTC 5389 & $37 \cdot 8$ & 78 & 68 & 63 & 25 & 37 & NT & 25 & NT \\
\hline \multicolumn{10}{|l|}{ Homology group 2} \\
\hline NCDO $2227^{\mathrm{T}}$ & $37 \cdot 2$ & 29 & NT & 100 & 100 & 44 & NT & 21 & NT \\
\hline NMH 2 & 38.5 & 44 & NT & 106 & 61 & 45 & NT & 10 & NT \\
\hline UNS 35 & $37 \cdot 5$ & 33 & NT & 102 & 57 & 29 & NT & NT & NT \\
\hline $415-87$ & $37 \cdot 5$ & 39 & NT & 103 & 60 & 35 & NT & 21 & NT \\
\hline \multicolumn{10}{|l|}{ Homology group 3} \\
\hline NCTC $10713^{T}$ & $38 \cdot 1$ & 32 & NT & 42 & 20 & 100 & 100 & 16 & NT \\
\hline $2405-81$ & $39 \cdot 2$ & 44 & NT & 28 & NT & 92 & NT & NT & NT \\
\hline NMH 10 & $38 \cdot 5$ & 66 & 39 & 40 & 9 & 81 & 50 & 30 & NT \\
\hline G5:3 & $38 \cdot 4$ & 53 & 32 & 23 & NT & 79 & 69 & NT & NT \\
\hline $2236-81$ & 39.0 & 46 & NT & 43 & NT & 76 & 59 & 19 & NT \\
\hline $1007-77$ & $39 \cdot 0$ & 62 & 12 & 46 & NT & 78 & 50 & NT & NT \\
\hline PC 4890 & $39 \cdot 5$ & 67 & 24 & 48 & 11 & 75 & 53 & NT & NT \\
\hline NCTC 11062 & $37 \cdot 8$ & 50 & 37 & 45 & NT & 74 & NT & NT & NT \\
\hline KR 687 & $38 \cdot 8$ & 37 & NT & 42 & 5 & 72 & 55 & 15 & NT \\
\hline NCTC 8037 & $38 \cdot 7$ & 55 & 26 & 51 & 26 & 69 & 60 & NT & NT \\
\hline KR 455 & $39 \cdot 0$ & 24 & NT & 36 & NT & 62 & 61 & NT & NT \\
\hline ATCC 9895 & $38 \cdot 2$ & 57 & 15 & 47 & 25 & 54 & 51 & 20 & NT \\
\hline \multicolumn{10}{|l|}{ Homology group 4} \\
\hline $85-81$ & $42 \cdot 7$ & 1 & NT & 10 & NT & 6 & NT & 100 & 100 \\
\hline SS-895 & $41 \cdot 5$ & 15 & NT & 14 & NT & 12 & NT & 93 & 62 \\
\hline $2156-81$ & $42 \cdot 0$ & 12 & NT & 28 & 2 & 17 & NT & 110 & 60 \\
\hline SS-898 & $42 \cdot 0$ & 2 & NT & 10 & NT & 11 & NT & 72 & NT \\
\hline \multicolumn{10}{|l|}{ S. sanguis } \\
\hline NCTC $7863^{\mathrm{T}}$ & $45 \cdot 0$ & 9 & NT & 10 & NT & 18 & NT & 33 & NT \\
\hline \multicolumn{10}{|l|}{ S. mitis } \\
\hline NCTC $3165^{\mathrm{T}}$ & $38 \cdot 8$ & 13 & NT & 13 & NT & 13 & NT & 19 & NT \\
\hline \multicolumn{10}{|l|}{ S. oralis } \\
\hline $\mathrm{LVGl}^{\mathrm{T}}\left(\mathrm{NCTC} 11427^{\mathrm{T}}\right)$ & $40 \cdot 5$ & 10 & NT & 11 & NT & 20 & NT & 15 & NT \\
\hline \multicolumn{10}{|l|}{ S. salivarius } \\
\hline NCTC $8618^{\mathrm{T}}$ & $41 \cdot 6$ & 5 & NT & 5 & NT & 7 & NT & 16 & NT \\
\hline \multicolumn{10}{|l|}{ S. vestibularis } \\
\hline $\mathrm{MMI}^{\mathrm{T}}\left(\mathrm{NCTC} 12166^{\mathrm{T}}\right)$ & $39 \cdot 0$ & 17 & NT & 17 & NT & 14 & NT & 23 & NT \\
\hline \multicolumn{10}{|l|}{ S. mutans } \\
\hline NCTC $10449^{\mathrm{T}}$ & $37 \cdot 0$ & 0 & NT & 2 & NT & 5 & NT & 18 & NT \\
\hline
\end{tabular}

* Only hybridizations showing $\geqslant 50 \%$ base sequence homology under optimum conditions were repeated under stringent conditions. Intra-homology group values are shown in bold print. NT, Not tested.

group 1, with the exception of strain AM 699, were assigned to 'S. milleri' biotype I in the API 20 STREP rapid identification system. Members of homology group 1 were either serologically ungroupable or belonged to Lancefield group $F$ and were further characterized by the production of hyaluronidase.

Strains of homology group 2 differed from those of group 1 by fermenting lactose and usually cellobiose and in being weakly haemolytic $(\alpha)$ or non-haemolytic $(\gamma)$. All strains were assigned to ' $S$. milleri' biotype II in the API 20 STREP rapid identification system. As with homology group 1, hyaluronidase was produced by all members of this group. No Lancefield serological groups were represented in homology group 2 . 


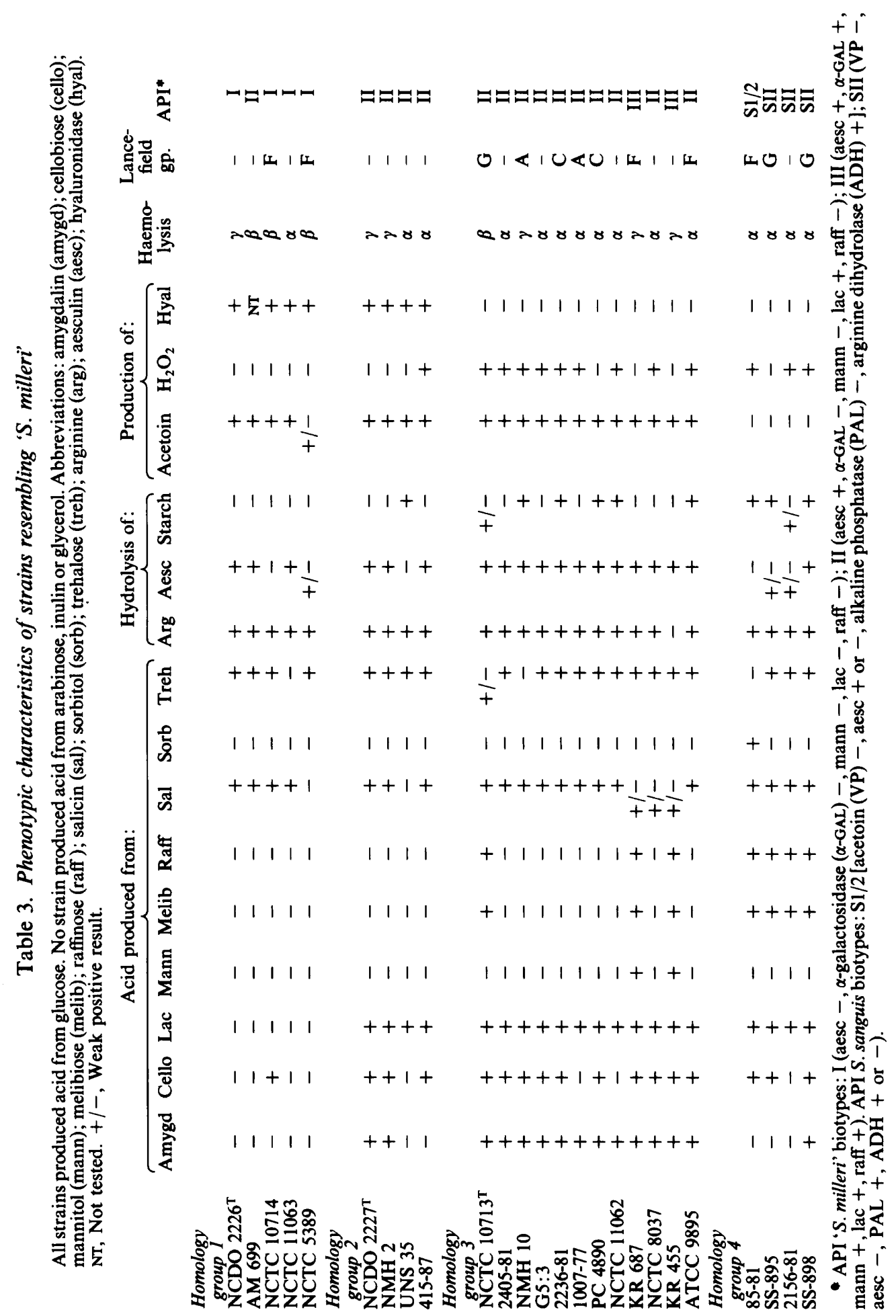




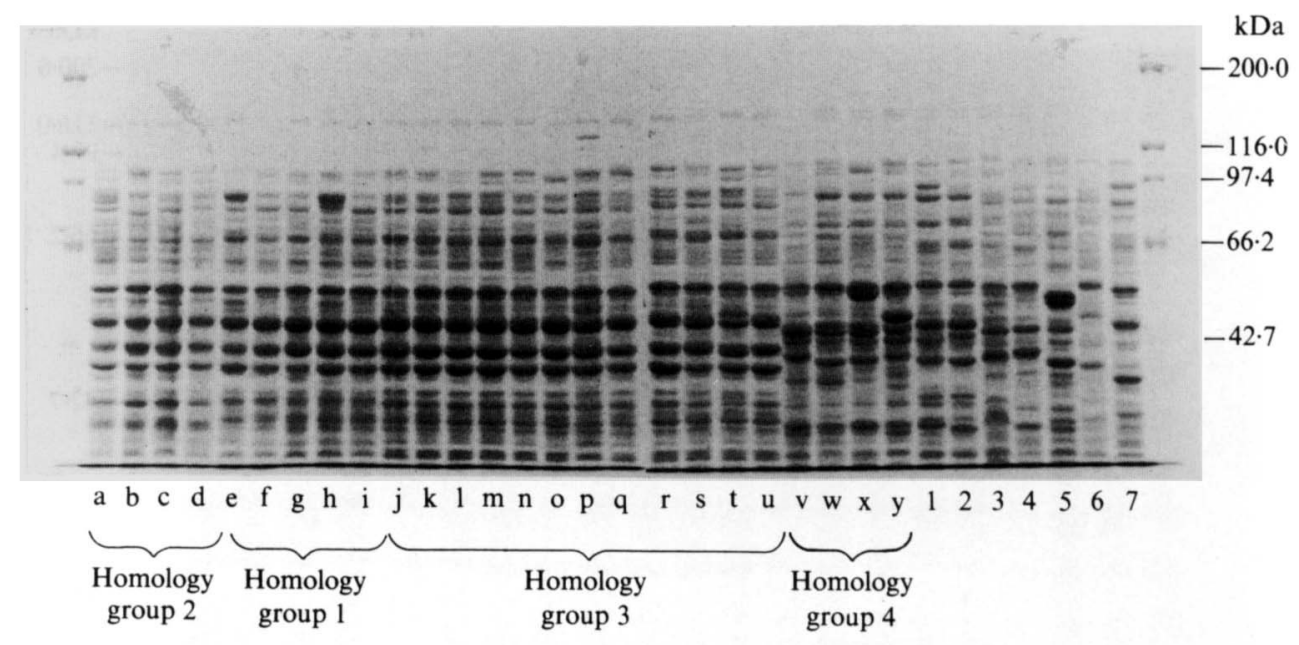

Fig. 1. SDS-PAGE (7\% acrylamide) of whole-cell-derived polypeptide patterns stained with Coomassie Brilliant Blue. Homology group 2: lane a, NCDO 2227; b, UNS 35; c, NMH 2; d, 415-87. Homology group 1 : lane e, NCDO 2226; f, NCTC 10714; g, NCTC 11063 ; h, NCTC 5389; i, AM 699. Homology group 3: lane j, NCTC 10713; k, PC 4890; 1, 1007-77; m, NMH 10; n, NCTC 11062; o, 2236-81; p, KR 687; q, 2405-81 ; r, NCTC 8037; s, KR 455; t, G5:3; u, ATCC 9895. Homology group 4: lane v, 85-81; w, SS-895; x, SS-898; y, 2156-81. Lane 1, S. sanguis (NCTC 7863); 2, S. mitis (NCTC 3165); 3, S. oralis (LVG1); 4, S. salivarius (NCTC 8618); 5, S. vestibularis (MM1); 6, S. mutans (NCTC 10449); 7, S. sobrinus SL-1 (ATCC 33478).

Strains of homology group 3 were characterized by their ability to ferment amygdalin and lactose and by the frequent fermentation of cellobiose and production of hydrogen peroxide. Strains in this group were also weakly or non-haemolytic $(\alpha, \gamma)$, with the exception of NCTC $10713(\beta)$, and serologically heterogeneous, with strains of Lancefield groups A, C and F as well as serologically ungroupable strains present. None of the 12 strains in homology group 3 produced hyaluronidase and most were assigned to ' $S$. milleri' biotype II in the API 20 STREP identification system, apart from two strains (KR 455 and KR 687) which fell into biotype III.

Homology group 4 strains differed from the other groups by being unable to produce acetoin. All four strains in this group fermented lactose and melibiose; three fermented cellobiose and raffinose, and three produced hydrogen peroxide. No strains of homology group 4 produced hyaluronidase and all were $\alpha$-haemolytic. These strains were serologically heterogeneous, with strains possessing Lancefield group antigens $F$ and $G$ as well as serologically ungroupable strains present. In the API 20 STREP identification system the strains in group 4 were assigned to $S$. sanguis biotype II (SS-895, SS-898, 2156-81) or to $S$. sanguis biotype $1 / 2$ (strain 85-81) although, with the exception of strain 2156-81, the level of confidence for these identifications was less than $56 \%$.

\section{SDS-PAGE polypeptide patterns}

The polypeptide profiles of the test strains together with those from selected type strains of other viridans streptococcal species are shown in Fig. 1. Strikingly similar polypeptide patterns were shared by strains of homology groups 1,2 and 3 . These were characterized by four dominant bands of approximate molecular masses $53 \cdot 3,45 \cdot 3,41 \cdot 3$ and $38.0 \mathrm{kDa}$. Considerable inter-strain heterogeneity was observed amongst the bands in the range $58 \cdot 3-106.0 \mathrm{kDa}$, even between strains belonging to the same DNA homology group (Figs 1 and 2). However, the band patterns of polypeptides in the lower size range of $25.5-34.0 \mathrm{kDa}$ were less heterogeneous and fell into three main pattern types corresponding to the DNA homology groups (Fig. 2).

Strains of homology group 4 gave polypeptide patterns that were clearly unrelated to those of DNA homology groups 1-3 (Fig. 1). With the exception of a dominant $53.3 \mathrm{kDa}$ band, which was present in virtually all streptococci examined here, there was little or no similarity between 


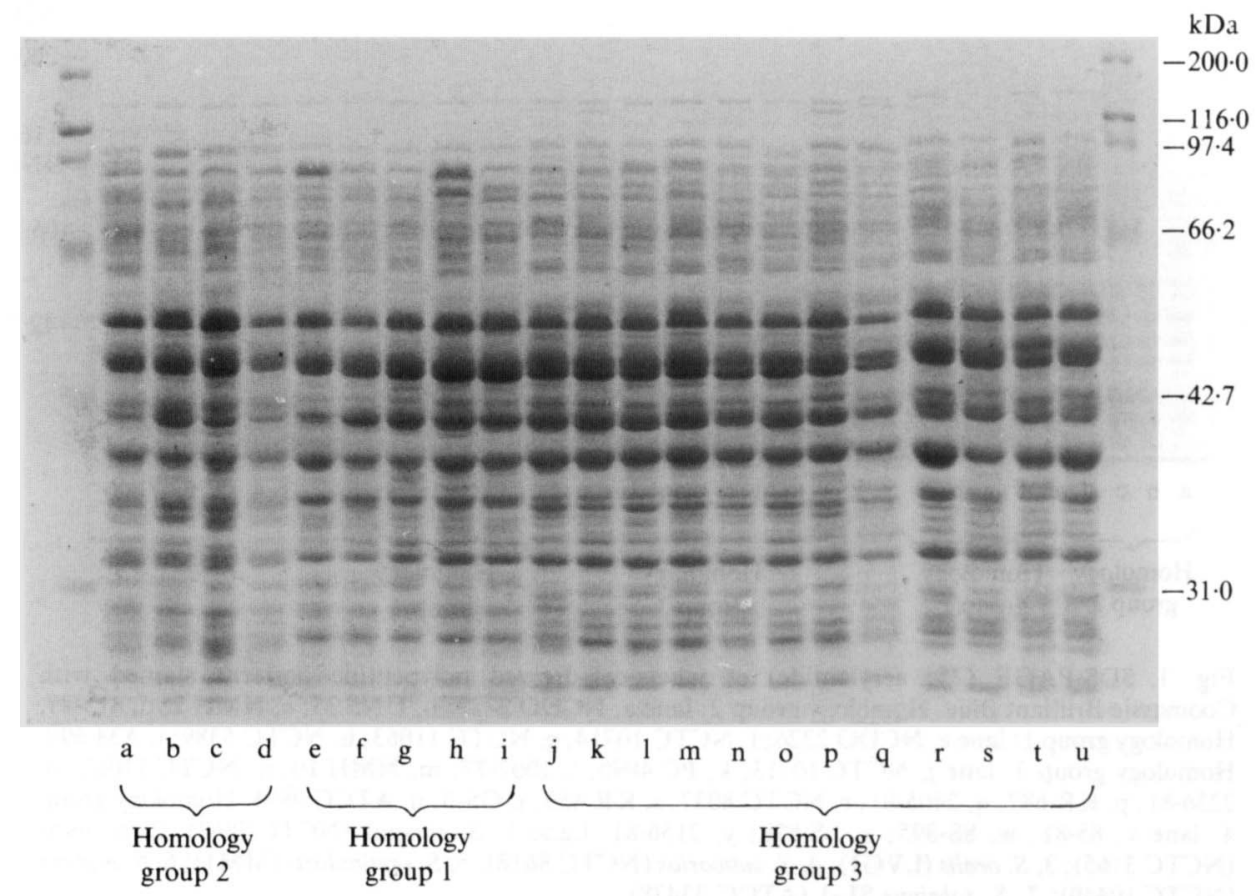

Fig. 2. SDS-PAGE (12\% acrylamide) of whole-cell-derived polypeptide patterns stained with Coomassie Brilliant Blue. Homology group 2: lane a, NCDO 2227; b, UNS 35; c, NMH 2; d, 415-87. Homology group 1 : lane e, NCDO 2226; f, NCTC 10714; g, NCTC 11063; h, NCTC 5389; i, AM 699. Homology group 3: lane j, NCTC 10713; k, PC 4890; l, 1007-77; m, NMH 10; n, NCTC 11062; o, 2236-81; p, KR 687; q, 2405-81; r, NCTC 8037; s, KR 455; t, G5:3; u, ATCC 9895.

the patterns of the strains in homology group 4 and those of homology groups 1-3. Considerable heterogeneity within group 4 was also noted throughout the 29-106 kDa range resolved on the $7 \%$ gel (Fig. 1), despite the obvious close relationship between these strains as shown by DNA-DNA hybridization.

\section{DISCUSSION}

The data obtained from the DNA studies and SDS-PAGE gels demonstrate that strains resembling ' $S$. milleri' consist of three distinct, albeit closely related, groups. The inclusion of the type strains of $S$. constellatus, $S$. intermedius and $S$. anginosus in separate DNA homology groups confirms and extends the results of Kilpper-Balz et al. (1984), who obtained DNA homology groups corresponding to $S$. anginosus and $S$. constellatus, with the type strain of $S$. intermedius (DSM 20573) remaining ungrouped. The formation of a fourth, more distantly related, genetic group by the variant strains of $S$. intermedius is in accord with the data obtained by Knight \& Shlaes (1988). Unfortunately these authors did not include reference strains of $S$. constellatus or $S$. anginosus in their study so it is not possible to equate any of the homology groups found by them with homology groups 1 and 3 of this study.

The conflicting data in the literature concerning the inclusion of strains resembling ' $S$. milleri' in a single homology group by some authors (Welborn et al., 1983; Farrow \& Collins, 1984; Ezaki et al., 1986; Coykendall et al., 1987) and the demonstration of several distinct DNA homology groups by others (Kilpper-Balz et al., 1984; Knight \& Shlaes, 1988) has most probably been due to the respective stringencies of the different methods employed. Such discrepancies have been recognized before (Bouvet \& Grimont, 1986; Coykendall \& Munzenmaier, 1978, 1979) and have been acknowledged as a likely cause for disagreement in previous studies on the 'S. milleri group' (Coykendall et al., 1987; Knight \& Shlaes, 1988). In addition, the fact that in some cases DNA-DNA hybridization studies have only been done on strains preselected on the 
basis of haemolysis type and lactose fermentation (Ezaki et al., 1986; Knight \& Shlaes, 1988) has made it difficult to draw conclusions regarding the ' $S$. milleri group' as a whole.

As concluded by previous authors (Kilpper-Balz et al., 1984; Knight \& Shlaes, 1988) there remains a need for reliable phenotypic tests or markers with which to differentiate the three homology groups within the ' $S$. milleri group'. Of the tests used in the present study, acid production from amygdalin and lactose, and the production of hydrogen peroxide and hyaluronidase seem the most useful. However, the assignment of freshly isolated strains to one or other of the genetic groups on the basis of these tests alone may well prove equivocal, as was found to be the case by Kilpper-Balz et al. (1984), where both lac ${ }^{+} / \mathrm{hyal}^{+}$and lac ${ }^{+} / \mathrm{hyal}^{-}$strains were found to belong to the $S$. constellatus DNA homology group. The observation by these authors that the type strain of $S$. intermedius did not produce hyaluronidase was not confirmed in the present study, where hyaluronidase production was found to be a characteristic of all strains in the $S$. intermedius homology group. Subsequently, we have also hybridized other versions of the $S$. intermedius type strain [i.e. DSM 20573 and CDC strain SS1090 (=ATCC 27823)] with NCDO 2227 . These gave $84 \%$ and $112 \%$ DNA base sequence homology, respectively, with NCDO 2227 (data not shown) and were also able to produce hyaluronidase.

The low level of DNA homology observed between strains comprising homology group 4 and all other streptococci examined indicates that these bacteria represent an as yet unrecognized species. Further studies with additional strains will be necessary to determine the true taxonomic status of these streptococci.

Although these data demonstrate a considerable degree of genetic heterogeneity within the ' $S$. milleri group', the relatively low numbers of strains that have, so far, confidently been assigned to one or other of the three homology groups, together with a lack of reliable phenotypic tests, precludes us from making formal taxonomic proposals at present.

\section{REFERENCES}

ANDREWES, F. W. \& HoRder, T. J. (1906). A study of the streptococci pathogenic for man. Lancet ii, 703-713.

Attebury, H. R., Sutter, V. L. \& Finegold, S. M. (1972). Effect of a partially chemically defined diet on human fecal flora. American Journal of Clinical Nutrition 25, 1391-1398.

Ball, L. C. \& PARKer, M. T. (1979). The cultural and biochemical characters of Streptococcus milleri strains isolated from human sources. Journal of Hygiene 82, 63-78.

Beighton, D., Russell, R. R. B. \& Hayday, H. (1981). The isolation and characterisation of Streptococcus mutans serotype h from dental plaque of monkeys (Macaca fascicularis). Journal of General Microbiology 124, 271-279.

Beighton, D., Hayday, H., Russell, R. R. B. \& Whiley, R. A. (1984). Streptococcus macacae sp. nov. from dental plaque of monkeys (Macaca fascicularis). International Journal of Systematic Bacteriology 34, 332-335.

Bisset, P. J. M. \& Davis, G. H. G. (1960). The Microbiol Flora of the Mouth. London: Heywood.

Bliss, E. A. (1937). Studies on minute hemolytic streptococci: serological differentiation. Journal of Bacteriology 33, 625-642.

Bouvet, P. J. M. \& Grimont, P. A. D. (1986). Taxonomy of the genus Acinetobacter with the recognition of Acinetobacter baumannii sp. nov., Acinetobacter haemolyticus sp. nov., Acinetobacter johnsonii sp. nov. and Acinetobacter junii sp. nov. and emended descriptions of Acinetobacter calcoaceticus and Acinetobacter lwoffii. International Journal of Systematic Bacteriology 36, 228-240.
Britten, R. J. \& Kohne, D. E. (1968). Repeated sequences in DNA. Science 161, 529-540.

Colman, G. \& Williams, R. E. O. (1972). Taxonomy of some human viridans streptococci. In Streptococci and Streptococcal Diseases, pp. 282-299. Edited by L. W. Wannamaker \& J. M. Matsen. New York: Academic Press.

Cookson, B., Talsania, H., Chinn, S. \& Phillips, I. (1989). A qualitative and quantitative study of the cellular fatty acids of 'Streptococcus milleri' with capillary gas chromatography. Journal of General Microbiology 135, 831-838.

Cowan, S. T. (1974). Cowan and Steel's Manual for the Identification of Medical Bacteria, 2nd edn. Cambridge: Cambridge University Press.

Coykendall, A. L. \& Munzenmaier, A. J. (1978). Deoxyribonucleic acid base sequence studies on glucan-producing and glucan-negative strains of Streptococcus mitior. International Journal of Systematic Bacteriology 28, 511-515.

Coykendall, A. L. \& Munzenmaier, A. J. (1979). Deoxyribonucleic acid hybridisation among strains of Actinomyces viscosus and Actinomyces naeslundii. International Journal of Systematic Bacteriology 29, 234-240.

Coykendall, A. L., Wesbecher, P. M. \& Gustafson, K. B. (1987). 'Streptococcus milleri', Streptococcus constellatus, and Streptococcus intermedius are later synonyms of Streptococcus anginosus. International Journal of Systematic Bacteriology 37, 222-228.

Crosa, J. H., Brenner, D. J. \& Falkow, S. (1973). Use of a single-strand nuclease for analysis of bacterial and plasmid deoxyribonucleic acid homo- and heteroduplexes. Journal of Bacteriology 115, 904-911. 
Deibel, R. M. \& Seeley, H. W., JR (1974). Streptococcaceae. In Bergey's Manual of Determinative Bacteriology, 8th edn, pp. 490-509. Edited by R. E. Buchanan \& N. E. Gibbons. Baltimore: Williams \& Wilkins.

DRUCKER, D. B. \& LEE, S. M. (1981). Fatty acid fingerprints of 'Streptococcus milleri', Streptococcus mitis, and related species. International Journal of Systematic Bacteriology 31, 219-225.

Drucker, D. B. \& LeE, S. M. (1983). Possible heterogeneity of Streptococcus milleri determined by DNA mol\% (guanine plus cytosine) measurement and physiological characterization. Microbios 38, 151-157.

Ezaki, T., Facklam, R., Takeuchi, N. \& YabuUchi, E. (1986). Genetic relatedness between the type strain of Streptococcus anginosus and minute-colonyforming beta-hemolytic streptococci carrying different Lancefield grouping antigens. International Journal of Systematic Bacteriology 36, 345-347.

FACKLAM, R. R. (1977). Physiological differentiation of viridans streptococci. Journal of Clinical Microbiology 5, 184-201.

FACKLAM, R. R. (1984). The major differences in the American and British Streptococcus taxonomy schemes with special reference to Streptococcus milleri. European Journal of Clinical Microbiology 3, 91-93.

FACKLAM, R. R. (1984). Streptococcus milleri: Reply to D. M. Yajko and W. K. Hadley. European Journal of Clinical Microbiology 4, 356.

FarRow, J. A. E. \& Collins, M. D. (1984). Taxonomic studies on streptococci of serological groups C, G and $\mathrm{L}$ and possibly related taxa. Systematic and Applied Microbiology 5, 483-493.

French, G. L., Talsania, H., Charlton, J. R. H. \& PhILliPs, I. (1989). A physiological classification of viridans streptococci by use of the API-20 STREP system. Journal of Medical Microbiology 28, 275-286.

GARVIE, E. I. (1976). Hybridization between the deoxyribonucleic acid of some strains of heterofermentative lactic acid bacteria. International Journal of Systematic Bacteriology 26, 116-122.

Gilmour, M. N., Whittam, T. S., Kilian, M. \& Selander, R. K. (1987). Genetic relationships among the oral streptococci. Journal of Bacteriology 169, 5247-5257.

Gossling, J. (1988). Occurrence and pathogenicity of the Streptococcus milleri group. Reviews of Infectious Diseases 10, 257-285.

GuTHOF, O. (1956). Über pathogene, vergrunende "Streptokokken": Streptokokkenbefunde bei dentogenen Abszessen und Infiltraten im Bereich der Mundhohle. Zentralblatt fur Bakteriologie, Parasitenkunde, Infektionskrankheiten und Hygiene, Abt. I, 166, 553-564.

HARDIE, J. M. (1986). Oral streptococci. In Bergey's Manual of Systematic Bacteriology, vol. 2, pp. 1054-1063. Edited by P. H. A. Sneath. Baltimore: Williams \& Wilkins.

Holdeman, L. V. \& Moore, W. E. C. (1974). New genus, Coprococcus, twelve new species, and emended descriptions of four previously described species of bacteria from human feces. International Journal of Systematic Bacteriology 24, 260-277.

KilpPeR-Balz, R., Williams, B. L., LutTIKeN, R. \&
SCHLEIFER, K. H. (1984). Relatedness of 'Streptococcus milleri' with Streptococcus anginosus and Streptococcus constellatus. Systematic and Applied Microbiology 5, 494-500.

K Night, R. G. \& ShlaEs, D. M. (1988). Physiological characteristics and deoxyribonucleic acid relatedness of Streptococcus intermedius strains. International Journal of Systematic Bacteriology 38, 19-24.

LABbe, M., Van der AuWera, P., GlupCzYNSKi, Y., Crockaert, F. \& Yourassowsky, E. (1985). Fatty acid composition of Streptococcus milleri. European Journal of Clinical Microbiology 4, 391-393.

LAEMMLI, U. K. (1970). Cleavage of structural proteins during the assembly of the head of bacteriophage T4. Nature, London 227 680-685.

LoNG, P. H. \& Bliss, E. A. (1934). Studies on minute hemolytic streptococci; isolation and cultural characteristics of minute beta-hemolytic streptococci. Journal of Experimental Medicine 60, 619-631.

LUTTICKEN, R., WENDORFF, U., LUTTICKEN, D., Johnson, E. A. \& WanNamaker, L. W. (1978). Studies on streptococci resembling Streptococcus milleri and on an associated surface-protein antigen. Journal of Medical Microbiology 11, 419-431.

MARMUR, J. \& DotY, P. (1962). Determination of the base composition of deoxyribonucleic acid from its thermal denaturation temperature. Journal of Molecular Biology 5, 109-118.

MEJARE, B. (1975). Characteristics of Streptococcus milleri and Streptococcus mitior from infected root canals. Odontologisk Revy 26, 291-308.

MeJARE, B. \& EdWARDSSON, S. (1975). Streptococcus milleri (Guthof): an indigenous organism of the human oral cavity. Archives of Oral Biology 20, 757-762.

Mirick, G. S., Thomas, L., Curnen, E. C. \& Horsfall, F. L. (1944). Studies on a nonhemolytic streptococcus isolated from the respiratory tract of human beings. I. Biological characteristics of Streptococcus MG. Journal of Experimental Medicine 80, 391-406.

OTTENS, H. \& WiNKLER, K. C. (1962). Indifferent and haemolytic streptococci possessing group-antigen $\mathbf{F}$. Journal of General Microbiology 28, 181-191.

OWEN, R. J. \& HiLl, L. R. (1979). The estimation of base compositions, base pairing and genome sizes of bacterial deoxyribonucleic acids. In Identification Methods for Microbiologists, 2nd edn. (Society for Applied Bacteriology, Technical Series no. 14), pp. 277-296. Edited by F. A. Skinner \& D. W. Lovelock. London: Academic Press.

PARKer, M. T. \& Ball, L. C. (1976). Streptococci and aerococci associated with systemic infection in man. Journal of Medical Microbiology 9, 275-302.

Poole, M. T. \& Wilson, G. (1979). Occurrence and cultural features of Streptococcus milleri in various body sites. Journal of Clinical Pathology 32, 764-768.

RUoFF, K. L. \& KUNZ, L. T. (1982). Identification of viridans streptococci isolated from clinical specimens. Journal of Clinical Microbiology 15, 920-925.

ShaH, H. N., Van SteEnbergen, T. J. M., HaRdie, J. M. \& DE GRAAFF, J. (1982). DNA base composition, DNA-DNA reassociation and isoelectrofocussing of proteins of strains designated Bacteroides oralis. FEMS Microbiology Letters 13, 125-130.

Shlaes, D. M., Lerner, P. I., Wolinsky, E. \& 
Gopalakrishna, K. V. (1981). Infections due to Lancefield Group F and related streptococci. ( $S$. milleri, S. anginosus). Medicine 60, 197-207.

SMITH, R. F. \& WiLleTt, N. P. (1968). Rapid plate method for screening hyaluronidase and chondroitin sulfatase-producing microorganisms. Applied Microbiology 16, 1434-1436.

WelboRn, P. R., Hadley, W. K., NewboRn, E. \& YAJKO, D. M. (1983). Characterization of strains of viridans streptococci by deoxyribonucleic acid hybridisation and physiological tests. International Journal of Systematic Bacteriology 33, 293-299.

WHILEY, R. A. (1987). A taxonomic study of oral streptococci. PhD thesis, University of London.

Whiley, R. A. \& Hardie, J. M. (1988). Streptococcus vestibularis sp. nov. from the human oral cavity.
International Journal of Systematic Bacteriology 38, 335-339.

Whiley, R. A., Hardie, J. M. \& Jackman, P. J. H. (1982). SDS-polyacrylamide gel electrophoresis of oral streptococci. In Basic Concepts of Streptococci and Streptococcal Diseases, (Proceedings of the VIIIth International Symposium on Streptococci and Streptococcal Disease, Reedbooks, Chertsey, Surrey, UK) pp. 61-62. Edited by S. E. Holm \& P. Christensen.

WhITTENBURY, R. (1964). Hydrogen peroxide formation and catalase activity in lactic acid bacteria. Journal of General Microbiology 35, 13-26.

YakushiJ, T., Konagawa, R., Oda, M. \& Inoue, M. (1988). Serological variation in oral Streptococcus milleri. Journal of Medical Microbiology 27, 145-151. 